\title{
A quantitative assessment of the gametogenic and androgenic properties of testicular steroids in hypophysectomized rats
}

\author{
P. M. Collins and W. N. Tsang \\ Department of Biological Sciences, University of California, Santa Barbara, CA 93106, U.S.A.
}

\begin{abstract}
Summary. The ability of testicular steroids to maintain the quantitative aspects of spermatogenesis was compared with reference to their androgenic properties. Hypophysectomized rats were injected daily with $0.2 \mathrm{mg}$ progesterone, $20 \alpha$ dihydroprogesterone, $3 \beta$-hydroxy-5 $\alpha$-pregnan-20-one, testosterone or testosterone propionate for 30 days beginning 2 days after the operation. Testosterone propionate was the most potent steroid tested both in terms of its peripheral androgenic effects and its ability to prevent the post-operative decline in the weight of the testis and seminiferous tubules and the numbers of germ cells throughout their differentiation. The natural androgen, testosterone, exhibited weak gametogenic properties and only partly maintained the normal measures of spermatogenesis. Progesterone exhibited low intrinsic androgenic potency yet was significantly more effective than testosterone in maintaining spermatogenesis; it prevented the degeneration of spermatocytes during the later stages of meiotic prophase and the reduction divisions resulting in an increased yield of step 7 spermatids. Low androgenic and gametogenic properties were exhibited by $20 \alpha$-dihydroprogesterone and $3 \beta$-hydroxy-5 $\alpha$-pregnan-20-one. These results may indicate that testosterone produced locally in the seminiferous tubules from progesterone is more effective in maintaining spermatogenesis than androgens entering from the circulation. Alternatively, progesterone may act more directly on the germ cells than previously envisaged.
\end{abstract}

\section{Introduction}

The seminiferous tubules share with the interstitial tissue the ability to convert progesterone to testosterone. While the level of production of testosterone by the seminiferous tubules is comparatively low it may help to provide the local concentration of androgens necessary for spermatogenesis (Bell, Vinson \& Lacy, 1971; Tsang, Collins \& Lacy, 1973a; Tsang, Lacy \& Collins, 1973b; Collins \& Lacy, 1974; Tcholakian \& Steinberger, 1978). In the seminiferous tubules, progesterone can also act as a common substrate for the formation of a series of hydroxylated and/or reduced $C_{21}$ steroids (Bell et al., 1971). Studies with seminiferous tubules isolated from the testis of developing and sterilized rats show that the level of activity of the $5 \alpha$-reductase and $20 \alpha$-hydroxysteroid dehydrogenase involved in the formation of these compounds is related to the level of spermatogenic function. The steroid $3 \beta$-hydroxy-5 $\alpha$-pregnan-20-one is a principal metabolite in incubations with tubules from developing or spermatogenically active testis, while 20a-dihydroprogesterone is formed in large amounts in regressed tubules (Tsang et al., 1973a, b; Collins \& Lacy, 1974; Collins \& Tsang, 1979). The ability of testosterone to maintain spermatogenesis has been extensively investigated (see Steinberger, 1971, for review). The possible role of other steroids which characterize the pattern of steroid metabolism in the seminiferous tubules has received little attention although it is known that $C_{21}$ steroids may possess gametogenic properties 
(Harris \& Bartke, 1975; Steinberger, Chowdhury, Tcholakian \& Roll, 1975). The present work evaluates the ability of progesterone, 20 $\alpha$-dihydroprogesterone and $3 \beta$-hydroxy-5 $\alpha$-pregnan20-one to maintain the quantitative aspects of spermatogenesis with reference to their androgenic potency. The effects of exogenous steroids on spermatogenesis have generally been assessed relative to the potent semi-synthetic androgen testosterone propionate. There appear to have been no previous quantitative studies on the effects of the natural steroid, testosterone, on spermatogenesis. To provide a more physiological expression of the gametogenic and androgenic properties of the administered $\mathrm{C}_{21}$ steroids their effects were compared to both testosterone and testosterone propionate.

\section{Materials and Methods}

Animals. Adult hypophysectomized Wistar rats with an initial body weight of $250-280 \mathrm{~g}$ were purchased from Simonsen Laboratories, Inc. (Gilroy, CA). Animals were maintained on a $12 \mathrm{~h}$ light: $12 \mathrm{~h}$ dark cycle (light phase $08: 00-20: 00 \mathrm{~h}$ ) on a diet of Rodent Laboratory Chow (Ralston Purina Company, St Louis, MO) and water supplemented with 5\% glucose. Animals received daily subcutaneous injections of $0.2 \mathrm{ml}$ sesame oil (intact and hypophysectomized controls) or the same volume of oil containing $0.2 \mathrm{mg}$ testosterone propionate, testosterone, progesterone, 20adihydroprogesterone or $3 \beta$-hydroxy-5 $\alpha$-pregnan-20-one (Sigma, St Louis, MO). Injections were begun 2 days after the operation and continued for 28 days. Animals were identified by clipping the ears and weighed at weekly intervals to obtain individual growth curves. Two hours after the final injections the animals were decapitated and blood collected for radioimmunoassay of testosterone. The weights of the testes, seminal vesicles (full and with secretion extruded), coagulating glands, ventral prostate, adrenal glands, epididymides and pituitary gland were recorded. The left testis and both epididymides were fixed in Bouin's solution. Paraffin-wax sections $(4 \mu \mathrm{m})$ were stained in PAS-haematoxylin or iron haematoxylin and orange G for histological analysis. The completeness of hypophysectomy was assessed on the basis of the inhibition of individual growth curves, adrenal regression, and the absence of pituitary remnants in the hypophysial fossa when examined under a binocular microscope.

Quantitation of testis function. The interstitial tissue and seminiferous tubules were isolated from the right testis by microdissection (Christensen \& Mason, 1965), drained and weighed to provide a direct quantitative evaluation of the degree of maintenance of these testicular components. Quantitative analysis of spermatogenesis was carried out 30 days after hypophysectomy when the tests of untreated rats are maximally regressed (Clermont \& Morgentaler, 1955). The number of Sertoli cell nuclei, type A spermatogonia, preleptotene, and mid-pachytene spermatocytes, and step 7 spermatids were counted in 20 circular cross-sections (largest and shortest diameters within 10\%) of tubules in stage VII of the cycle of the seminiferous epithelium (Clermont \& Harvey, 1967; Sivelle, McNeilly \& Collins, 1978). Germ cell counts were corrected for differences in their nuclear diameters (Abercrombie, 1946) and for tubule shrinkage by reference to the number of Sertoli cells in intact control as compared to experimental groups (Clermont \& Morgentaler, 1955).

Peripheral androgenic effects. The chronic effects of hormone therapy on peripheral androgen levels were indirectly assessed by reference to the accessory sex organ weights, secretory content of the seminal vesicles and fructose concentrations in the coagulating glands determined by a colorimetric method (Mann, Davies \& Humphrey, 1949). Plasma testosterone was measured directly by radioimmunoassay using a previously validated (Collins, Collins, McNeilly \& Tsang, 1978) liquid-phase system with a tritiated antigen and a specific antiserum to testosterone-7 $\alpha$ carboxymethyl-thioether-bovine serum albumin (Miles-Yeda Ltd, Elkhart, IN). The antiserum cross-reacted with testosterone propionate $(0.03 \%)$, progesterone $(0.007 \%), 20 \alpha$-dihydroprogesterone $(0.003 \%)$ and $3 \beta$-hydroxy-5 $\alpha$-pregnan-20-one $(0.001 \%)$ when measured at the level of $50 \%$ of total binding. The minimum concentration of testosterone which gave significantly lower 
$(P<0.05)$ binding than zero amounts of competing steroid (sensitivity) was $6.25 \mathrm{pg} / \mathrm{tube}$. The intra-assay coefficient of variation of a plasma sample with a mean concentration of $4.8 \pm 0 \cdot 1$ (s.e.m.) $\mathrm{ng} / \mathrm{ml}$ measured 8 times in the same assay was $5.7 \%$. The inter-assay coefficient of variation of a plasma sample measured in 7 separate assays at a mean concentration of $9 \cdot 6 \pm 0 \cdot 2$ (s.e.m.) $\mathrm{ng} / \mathrm{ml}$ was $5 \cdot 9 \%$.

\section{Results}

Body, testis and testicular component weights (Table 1)

Hypophysectomy resulted in a severe suppression of growth which was not affected by steroid therapy. The final body weight in all hypophysectomized groups was approximately $50 \%$ of that of the intact controls. In untreated hypophysectomized animals the weights of the seminiferous tubules were less than $20 \%$ of the normal value. Testis and tubule weights in relation to the intact control values were 55 and $62 \%$ respectively, in the testosterone propionate-treated animals and 38 and $36 \%$ respectively in those treated with testosterone. Treatment with $20 \alpha$-dihydroprogesterone and $3 \beta$-hydroxy-5 $\alpha$-pregnan-20-one produced barely detectable increases in testis and tubule

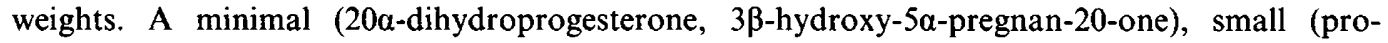
gesterone and testosterone) or moderate (testosterone propionate) increase in the weight of interstitial tissue was noted in steroid-treated animals.

Table 1. Body weight and testis weights, and weight and dimension of testicular components (mean \pm s.e.m.) of control and steroid-treated hypophysectomized (hypox.) rats

\begin{tabular}{|c|c|c|c|c|c|}
\hline $\begin{array}{l}\text { Experimental } \\
\text { groups }\end{array}$ & $\begin{array}{l}\text { No. of } \\
\text { animals }\end{array}$ & $\begin{array}{l}\text { Body wt } \\
(\mathrm{g})\end{array}$ & $\begin{array}{l}\text { Wt of testes } \\
\text { (mg) }\end{array}$ & $\begin{array}{l}\text { Wt of tubules per } \\
\text { testis (mg) }\end{array}$ & $\begin{array}{c}\text { Wt of interstitial } \\
\text { tissue per testis }(\mathrm{mg})\end{array}$ \\
\hline Intact control & 10 & $\begin{array}{l}386 \cdot 10 \\
\pm 8 \cdot 86\end{array}$ & $\begin{array}{l}2986 \cdot 19^{c} \\
\pm 82 \cdot 27\end{array}$ & $\begin{array}{l}1015.98^{c} \\
\pm 31.55\end{array}$ & $\begin{array}{r}89.94^{\mathrm{c}} \\
\pm 5.45\end{array}$ \\
\hline Hypox. & 7 & $\begin{array}{r}206.86 \\
\pm 3.90\end{array}$ & $\begin{array}{r}527.69 \\
\pm 34.60\end{array}$ & $\begin{array}{l}148 \cdot 36 \\
\pm 8 \cdot 31\end{array}$ & $\begin{array}{r}22 \cdot 30 \\
\pm 1 \cdot 44\end{array}$ \\
\hline Hypox. + testosterone & 6 & $\begin{array}{r}213.00 \\
\pm 2.08\end{array}$ & $\begin{array}{l}1138 \cdot 10^{c . d} \\
\pm 136 \cdot 27\end{array}$ & $\begin{array}{l}366 \cdot 45^{\text {c.e }} \\
\pm 52.83\end{array}$ & $\begin{array}{r}34.45^{\mathrm{c}} \\
\pm 1.86\end{array}$ \\
\hline $\begin{array}{l}\text { Hypox. + testosterone } \\
\text { propionate }\end{array}$ & 8 & $\begin{array}{r}216 \cdot 38 \\
\pm 4.83\end{array}$ & $\begin{array}{l}2199 \cdot 21^{\mathrm{c}} \\
\pm 149 \cdot 32\end{array}$ & $\begin{array}{c}808 \cdot 55^{\circ} \\
\pm 58.08\end{array}$ & $\begin{array}{l}53 \cdot 88^{\mathfrak{c}} \\
\pm 2 \cdot 48\end{array}$ \\
\hline Hypox. + progesterone & 8 & $\begin{array}{l}209 \cdot 38 \\
\pm 2 \cdot 98\end{array}$ & $\begin{array}{r}1640 \cdot 76^{c} \\
\pm 129.99\end{array}$ & $\begin{array}{r}628.94^{\mathrm{c}} \\
\pm 56.84\end{array}$ & $\begin{array}{l}31.29^{\circ} \\
\pm 4.24\end{array}$ \\
\hline $\begin{array}{c}\text { Hypox. }+3 \beta \text {-hydroxy- } \\
5 \alpha \text {-pregnan-20-one }\end{array}$ & 7 & $\begin{array}{l}192.00 \\
\pm 3 \cdot 28\end{array}$ & $\begin{array}{l}663 \cdot 90^{\mathrm{a}} \\
\pm 31 \cdot 16\end{array}$ & $\begin{array}{l}197.21^{b} \\
\pm 8.59\end{array}$ & $\begin{array}{r}28 \cdot 21^{\mathrm{a}} \\
\pm 1 \cdot 39\end{array}$ \\
\hline $\begin{array}{l}\text { Hypox. }+20 \alpha \text {-dihydro- } \\
\text { progesterone }\end{array}$ & 8 & $\begin{array}{l}197 \cdot 50 \\
\pm 2 \cdot 30\end{array}$ & $\begin{array}{l}704 \cdot 73^{\mathrm{b}} \\
\pm 25 \cdot 70\end{array}$ & $\begin{array}{l}240 \cdot 41^{\mathrm{c}} \\
\pm 12 \cdot 30\end{array}$ & $\begin{array}{l}27.53^{\circ} \\
\pm 1.93\end{array}$ \\
\hline
\end{tabular}

${ }^{\mathrm{a} P} P 0.05,{ }^{\mathrm{b}} P<0.01,{ }^{\mathrm{c}} P<0.001$, compared with hypophysectomized animals; ${ }^{\mathrm{d}} P<0.05,{ }^{\mathrm{e}} P<0.01$, for testosterone- as compared with progesterone-treated animals (Student's $t$ test).

\section{Accessory sex organs (Table 2)}

In untreated hypophysectomized animals the weights of the seminal vesicles, seminal vesicle secretion, prostate, and epididymides were significantly reduced to $14,0 \cdot 5,4 \cdot 2$ and $20 \%$ of intact control values respectively. Testosterone propionate-treated rats showed significant hypertrophy of the seminal vesicles and prostate while the weight of the epididymides was maintained within the normal range. Testosterone maintained the weight and secretory content of the accessory sex organs close to or slightly above the intact control level. Progesterone barely stimulated the seminal vesicles and prostate but increased the weight of the epididymides to about half the normal 


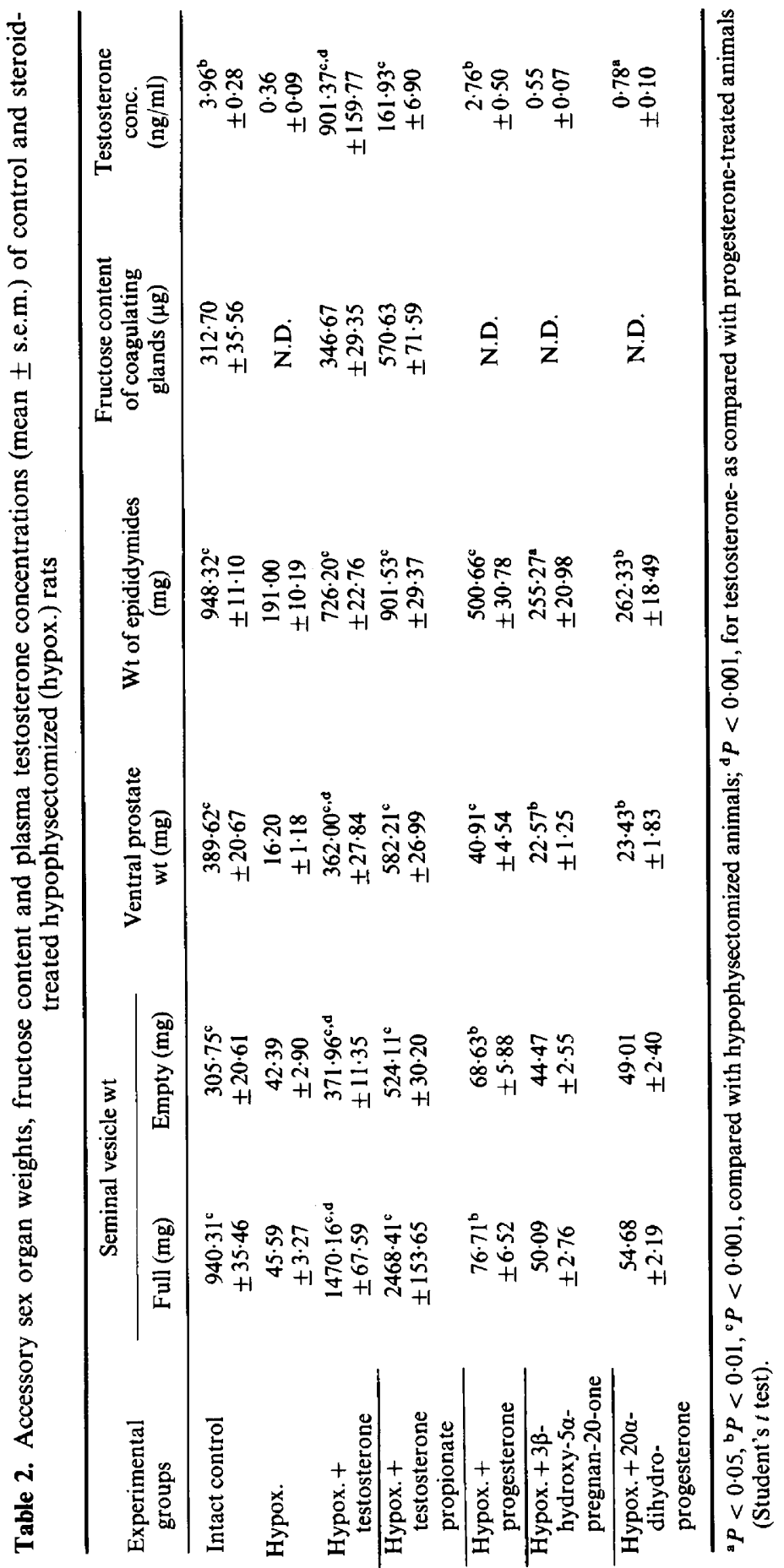


value. There was very slight or no stimulation of the accessory sex organs with $3 \beta$-hydroxy$5 \alpha$-pregnan-20-one and $20 \alpha$-dihydroprogesterone.

\section{Cell counts (Table 3 )}

Hypophysectomy resulted in a significant reduction in the number of each germ cell type. Administration of testosterone propionate restored the germ cell population to close to normal levels. Animals receiving testosterone and progesterone showed a significant increase in the number of pachytene spermatocytes and step 7 spermatids. The quantitative change in both cell types was significantly greater in the progesterone as compared to the testosterone-treated group. Administration of $3 \beta$-hydroxy-5 $\alpha$-pregnan-20-one and $20 \alpha$-dihydroprogesterone had no effect on germ cell numbers. The number of Sertoli cells per tubule cross-section was significantly increased over intact control values in hypophysectomized animals receiving no steroid, $3 \beta$ hydroxy-5a-pregnan-20-one or $20 \alpha$-dihydroprogesterone. Sertoli cell numbers were restored by injections of testosterone propionate, testosterone or progesterone.

Table 3. Mean \pm s.e.m. number of Sertoli* and germ cells $\dagger$ per cross-section of seminiferous tubule at stage VII of the cycle of the seminiferous epithelium in control and steroid-treated hypophysectomized (hypox.) rats

\begin{tabular}{|c|c|c|c|c|c|}
\hline $\begin{array}{l}\text { Experimental } \\
\text { groups }\end{array}$ & $\begin{array}{l}\text { Sertoli } \\
\text { cells }\end{array}$ & $\begin{array}{c}\text { Type A } \\
\text { spermatogonia }\end{array}$ & $\begin{array}{l}\text { Preleptotene } \\
\text { spermatocytes }\end{array}$ & $\begin{array}{c}\text { Pachytene } \\
\text { spermatocytes }\end{array}$ & $\begin{array}{c}\text { Step } 7 \\
\text { spermatids }\end{array}$ \\
\hline Intact control & $\begin{aligned} & 6.64^{\mathrm{c}} \\
\pm & 0.30\end{aligned}$ & $\begin{aligned} & 1 \cdot 11^{\mathrm{a}} \\
\pm & 0 \cdot 16\end{aligned}$ & $\begin{array}{l}23 \cdot 10^{c} \\
\pm 0 \cdot 90\end{array}$ & $\begin{array}{l}25.90^{\mathrm{c}} \\
\pm 1.28\end{array}$ & $\begin{array}{l}90 \cdot 66^{\mathrm{c}} \\
\pm 2 \cdot 50\end{array}$ \\
\hline Hypox. & $\begin{array}{r}9 \cdot 01 \\
\pm 0.46\end{array}$ & $\begin{array}{r}0.58 \\
\pm 0.15\end{array}$ & $\begin{array}{r}16 \cdot 31 \\
\pm 1 \cdot 10\end{array}$ & $\begin{array}{r}3.51 \\
\pm 0.86\end{array}$ & $\begin{array}{r}4.42 \\
\pm 1.82\end{array}$ \\
\hline Hypox. + testosterone & $\begin{aligned} & 6.32^{\mathrm{b}} \\
\pm & 0.56\end{aligned}$ & $\begin{array}{r}0.58 \\
\pm 0.14\end{array}$ & $\begin{array}{r}18.68 \\
\pm 2.02\end{array}$ & $\begin{aligned} & 10 \cdot 57^{\mathrm{b}} \\
\pm & 2 \cdot 41\end{aligned}$ & $\begin{array}{l}29 \cdot 23^{b, d} \\
\pm 9 \cdot 39\end{array}$ \\
\hline $\begin{array}{l}\text { Hypox. + testosterone } \\
\text { propionate }\end{array}$ & $\begin{aligned} & 5 \cdot 20^{\mathrm{c}} \\
\pm & 0 \cdot 25\end{aligned}$ & $\begin{array}{r}0.66 \\
\pm 0.13\end{array}$ & $\begin{array}{l}21 \cdot 01^{\mathrm{b}} \\
\pm 1 \cdot 15\end{array}$ & $\begin{array}{r}21.48^{\mathrm{c}} \\
\pm 1.62\end{array}$ & $\begin{array}{r}78 \cdot 47^{c} \\
\pm 8 \cdot 63\end{array}$ \\
\hline Hypox. + progesterone & $\begin{aligned} & 7 \cdot 17^{\mathrm{b}} \\
\pm & 0.41\end{aligned}$ & $\begin{array}{r}0.56 \\
\pm 0.16\end{array}$ & $\begin{array}{r}18.44 \\
\pm 1.19\end{array}$ & $\begin{array}{r}13 \cdot 98^{\mathrm{c}} \\
\pm 1 \cdot 14\end{array}$ & $\begin{array}{r}64 \cdot 39^{c} \\
\pm 3 \cdot 24\end{array}$ \\
\hline $\begin{array}{l}\text { Hypox. }+3 \beta \text {-hydroxy- } 5 \alpha- \\
\text { pregnan-20-one }\end{array}$ & $\begin{array}{r}8.29 \\
\pm 0.69\end{array}$ & $\begin{array}{r}0.48 \\
\pm 0.16\end{array}$ & $\begin{array}{r}13 \cdot 20 \\
\pm 2 \cdot 10\end{array}$ & $\begin{array}{r}3.24 \\
\pm 0.93\end{array}$ & $\begin{array}{r}9.80 \\
+3.57\end{array}$ \\
\hline $\begin{array}{l}\text { Hypox. }+20 \alpha \text {-dihydro- } \\
\text { progesterone }\end{array}$ & $\begin{array}{r}8 \cdot 30 \\
\pm 0.71\end{array}$ & $\begin{array}{r}0.57 \\
\pm 0.11\end{array}$ & $\begin{array}{r}13.19 \\
\pm 1.39\end{array}$ & $\begin{array}{r}4.28 \\
\pm 0.87\end{array}$ & $\begin{array}{r}4.70 \\
\pm 1.85\end{array}$ \\
\hline
\end{tabular}

* Corrected by Abercrombie's formula.

$\dagger$ Corrected by Abercrombie's formula and Sertoli correcting factor.

${ }^{a} P<0.05,{ }^{b} P<0.01,{ }^{c} P<0.001$, compared with hypophysectomized animals; $P<0.01$, for testosterone- as compared with progesterone-treated animals (Student's $t$ test).

\section{Testosterone and fructose values}

After hypophysectomy circulating testosterone concentrations fell to $<10 \%$ of normal values (Table 2). In the testosterone- and testosterone propionate-treated animals, plasma testosterone was enormously elevated to 228 and 41 times that of intact control values respectively. Administration of progesterone failed to restore normal peripheral testosterone levels. Testosterone concentrations remained close to the values in hypophysectomized animals in those treated with $3 \beta$-hydroxy-5 $\alpha$-pregnan-20-one and $20 \alpha$-dihydroprogesterone. The fructose content of the coagulating glands was below the limits of detectability in the hypophysectomized controls and in animals receiving progesterone, $3 \beta$-hydroxy-5 $\alpha$-pregnan-20-one or $20 \alpha$-dihydroprogesterone (Table 2). Fructose concentrations ( $\mu \mathrm{g} /$ gland) were restored to normal levels by testosterone and were significantly increased by testosterone propionate. 


\section{Discussion}

The role of exogenous androgens in the regulation of spermatogenesis has been evaluated progressively over the past 50 years. Early experiments using extracts of male sex hormone (Walsh, Cuyler \& McCullagh, 1934; Nelson \& Gallagher, 1936) and later crystalline androgens (Nelson, 1937) demonstrated that spermatogenesis could be maintained in hypophysectomized adult animals if therapy was begun shortly after the operation. With the development of testosterone propionate for clinical use this synthetic steroid has been widely used as a reference androgen (Cutuly, Cutuly \& McCullagh, 1938; Cutuly, 1942; Leathem, 1944; Boccabella, 1963). Testosterone propionate rather than testosterone appears to have been used in all quantitative assessments of the role of the testicular hormone in germ cell development and in numerical comparisons of the relative effectiveness of other steroids (Clermont \& Harvey, 1967; Chowdhury \& Steinberger, 1975; Harris \& Bartke, 1975; Chowdhury, 1979; Chowdhury \& Tcholakian, 1979). Testosterone propionate proved to be the most potent steroid tested both in terms of its peripheral androgenic properties and its ability to maintain germ cell numbers. In accordance with previous reports replacement therapy with testosterone propionate at a dose level which excessively stimulated the accessory sex organs (Table 2) maintained the numbers of different germ cell types close to normal values (Table 1). In contrast, the natural steroid testosterone exhibited weak gametogenic properties at a dose level which enormously elevated circulating concentrations of the hormone and maintained the accessory organs at or above their normal weight and secretory condition (Table 2). Testosterone only partly prevented the post-operative decline in the weight of the testis and seminiferous tubules, and in the numbers of pachytene and step 7 spermatids. Each of these indicators of spermatogenic function was $60-70 \%$ below control values (Tables 1 and 3). The present work is, to our knowledge, the first quantitative determination of the ability of the natural androgen, testosterone, to maintain the germ cell population of the testis. Progesterone was the most potent of the natural steroids tested and proved significantly more effective than testosterone in maintaining the weights of the seminiferous tubules and testis (Table 3). Progesterone was particularly effective in sustaining the development of the pachytene spermatocytes through the remaining stages of meiotic prophase and the reduction divisions. The gametogenic potency of progesterone was comparable to testosterone propionate during this period of spermatogenesis and both steroids maintained the ratio of pachytene spermatocytes to step 7 spermatids close to the theoretical maximum value of 1:4 (Table 1). Circulating concentrations of testosterone in the progesterone-treated group were negligible compared with animals receiving an equivalent amount of testosterone $(0.31 \%)$ and the seminal vesicles and prostate were barely stimulated above those of hypophysectomized control animals (Table 2). The increase in weight of the epididymis in progesterone-treated animals was due partly to the accumulation of large numbers of spermatozoa in the cauda and caput regions of this organ. The steroids $20 \alpha$-dihydroprogesterone and $3 \beta$-hydroxy-5 $\alpha$-pregnan-20-one exhibited no gametogenic activity and very weak androgenic potency (Tables 1,2 and 3). The gametogenic properties of $\mathrm{C}_{21}$ steroids which are intermediates in testosterone biosynthesis but have low intrinsic androgenic activity have been attributed to their bioconversion to androgens (Harris \& Bartke, 1975; Steinberger et al., 1975). The site of this conversion is unresolved. In confirmation of previous observations (Harris \& Bartke, 1975; Steinberger et al., 1975) there appeared to be little peripheral formation of androgens as evidenced by the atrophic condition of the accessory sex organs and the low circulating concentrations of testosterone in animals receiving $\mathrm{C}_{21}$ steroids (Table 2). The administration of $\mathrm{C}_{21}$ steroids increases the concentration of testosterone in the rete testis fluid (Harris \& Bartke, 1975) and testicular tissue (Parvinen, Hurme \& Niemi, 1970; Steinberger et al., 1975), suggesting that these precursors may be metabolized to testosterone within the testis. In intact animals the Leydig cells are the principal site of circulating androgens and significant amounts of testosterone may be channelled directly from the interstitium to the seminiferous tubules (Müller, 1957; Fawcett, Heidger \& Leak, 1969). The Leydig cells of hypophysectomized animals appear to have a limited ability fo produce and secrete androgen. After hypophysectomy 
the Leydig cells show histological signs of severe regression (Nelson, 1937; Cutuly et al., 1938; Taché, Selye, Szabo \& Taché, 1973; Harris \& Bartke, 1975). The present direct quantitative estimate shows that the interstitium atrophies to $\sim 25 \%$ of its normal weight after withdrawal of pituitary hormones (Table 3). There was a small to moderate increase in the amount of interstitial tissue recovered from steroid-treated animals (Table 3). This increase appeared to be generally related to the androgenic potency of the administered compound and is presumably due to the direct stimulation of as yet unidentified cellular elements. The concentrations of testosterone in testicular venous blood (Harris \& Bartke, 1975) and peripheral plasma (Harris \& Bartke, 1975; Table 2) of hypophysectomized animals receiving $C_{21}$ steroids are very low and it is unlikely that the increase in interstitial weight in steroid-treated animals is accompanied by a corresponding increase in the functional state of the Leydig cells. $\mathrm{C}_{21}$ steroids can pass from the general circulation into the seminiferous tubules (Parvinen et al., 1970; Cooper \& Waites, 1975) and in-vitro studies indicate that the tubules are able to metabolize these compounds to testosterone (Christensen \& Mason, 1965; Bell et al., 1971). After surgical or chemical ablation of pituitary function, the activity of enzymes involved in androgen biosynthesis is markedly reduced (Lacy, Fyson, Collins, Tsang \& Pettitt, 1973; Steinberger \& Ficher, 1973). However, it has been suggested that the seminiferous tubules of hypophysectomized rats, when provided with precursor steroids, may be able to provide sufficient local concentrations of androgens for spermatogenesis (Harris \& Bartke, 1975). The concept of intratesticular conversion of exogenous steroids to androgens was developed to explain the approximately equivalent or inferior effects of $\mathrm{C}_{21}$ steroids when compared to testosterone propionate (Harris \& Bartke, 1975; Steinberger et al., 1975). This hypothesis requires qualification to explain the present demonstration of the superior gametogenic effects of progesterone as compared to testosterone. The relative gametogenic potency of these two steroids does not seem to be due to differences in their rate of uptake by the seminiferous tubules. In fact the data of Cooper \& Waites (1975) indicate that testosterone enters the tubules from the circulation more rapidly than progesterone. If the maintenance of spermatogenesis by progesterone is due to its conversion to testosterone in the testis, then a possible explanation for the greater gametogenic potency of progesterone compared to testosterone is that androgens produced locally, possibly as a physiological function of the seminiferous tubules, are more effective than those entering via the circulation. Nevertheless, the weak gametogenic properties of testosterone relative to less potent androgens which are not precursors in testosterone biosynthesis cannot be readily explained in these terms (Nelson, 1937; Nelson \& Gallagher, 1936). These classical studies remain an enigma in the context of current concepts of the androgen dependence of spermatogenesis. An alternative explanation for the greater relative gametogenic potency of progesterone is that this steroid is able to maintain the germinal epithelium of hypophysectomized rats more directly than previously envisaged (Collins \& Tsang, 1979).

The authors thank Linda Lee Hahn for the preparation of this manuscript. This work was supported by NSF Grant No. PCM-8104108 and the Committee on Research, University of California.

\section{References}

Abercrombie, M. (1946) Estimation of nuclear population from microtome secilions. Anat. Rec. 94, 239-247.

Bell, J.B.G., Vinson, G.P. \& Lacy, D. (1971) Studies on the structure and function of the mammalian testis. III. In vitro steroidogenesis by the seminiferous tubules of rat testis. Proc. $R$. Soc. Lond. B 176, $433-443$.
Boccabella, A.V. (1963) Reinitiation and restoration of spermatogenesis with testosterone propionate and other hormones after a long-term post-hypophysectomy regression period. Endocrinology 72, 787-798.

Chowdhury, A.K. (1979) Dependence of testicular germ cells on hormones: a quantitative study in hypophysectomized testosterone-treated rats. $J$. Endocr. 82, 331-340. 
Chowdhury, A.K. \& Steinberger, E. (1975) A quantitative study of spermatogenesis in hypophysectomized, steroid-treated rats. Anat. Rec. 181, 332, Abstr.

Chowdhury, A.K. \& Tcholakian, R.K. (1979) Effects of various doses of testosterone propionate on intratesticular and plasma testosterone levels and maintenance of spermatogenesis in adult hypophysectomized rats. Steroids 34, 151-162.

Christensen, A.K. \& Mason, N.R. (1965) Comparative ability of seminiferous tubules and interstitial tissue of rat testes to synthesize androgens from progesterone-4- ${ }^{14} \mathrm{C}$ in vitro. Biochim. Biophys. Acta 164 , 421, Abstr.

Clermont, Y. \& Harvey, S.C. (1967) Effects of hormones on spermatogenesis in the rat. Ciba Fdn Colloq. Endocr. 16, 173-196.

Clermont, Y. \& Morgentaler, H. (1955) Quantitative study of spermatogeresis in the hypophysectomized rat. Endocrinology 57, 369-382

Collins, P. \& Lacy, D. (1974) Studies on the structure and function of the mammalian testis. IV. Steroid metabolism in vitro by isolated interstitium and seminiferous tubules of rat testis after heat sterilization. Proc. $R$. Soc. Lond. B. 186, 37-51.

Collins, P.M. \& Tsang, W.N. (1979) An assessment of the function of the seminiferous tubules and interstitium of the rat testis following ligation of the vasa efferentia. Biol. Reprod. 20, 671-680.

Collins, P.M., Collins, W.P., McNeilly, A.S. \& Tsang, W.N. (1978) Plasma FSH, LH and testosterone levels in the male rat during degeneration of the germinal epithelium caused by severe heat-treatment or ligation of the vasa efferentia. J. Reprod. Fert. 54, 285-291.

Cooper, T.G. \& Waites, G.M.H. (1975) Steroid entry into rete testis fluid and the blood-testis barrier. $J$. Endocr. 65, 195-205.

Cutuly, E. (1942) A study on spermatogenesis in rats. Am. J. Physiol. 137, 521-526.

Cutuly, E., Cutuly, E.C. \& McCullagh, D.R. (1938) Spermatogenesis in immature hypophysectomized rats injected with androgens. Proc. Soc. exp. Biol. Med. 38, 818-823.

Fawcett, D.W., Heidger, P.M. \& Leak, L.V. (1969) Lymph vascular system of the interstitial tissue of the testis as revealed by electron microscopy. $J$. Reprod. Fert. 19, 109-119.

Harris, M.E. \& Bartke, A. (1975) Maintenance of rete testis fluid testosterone and dihydrotestosterone levels by pregnenolone and other $C_{21}$ steroids in hypophysectomized rats. Endocrinology 96, 1396-1402.

Lacy, D., Fyson, P., Collins, P., Tsang, W.N. \& Pettitt, A.J. (1973) Progress in the development of hormonebased contraceptives for the human male with the laboratory rat as a model. $A d v$. Biosci. 10, 27-62.

Leathem, J.H. (1944) Influence of testosterone propionate on the adrenals and testes of hypophysectomized rats. Anat. Rec. 89, 155-161.
Mann, T., Davies, D.V. \& Humphrey, G.F. (1949) Fructose and citric acid assay in the secretions of the accessory glands of reproduction as indicator tests of male sex hormone activity. $J$. Endocr. 6, 75-85.

Müller, I. (1957) Kanälchen-und capillararchitektonik des rattenhodens. Z. Zellforsch. mikrosk. Anat. 45, $522-537$.

Nelson, W.O. (1937) Some factors involved in the control of the gametogenic and endocrine functions of the testis. Cold Spring Harb. Symp. quant. Biol. 5, $123-135$.

Nelson, W.O. \& Gallagher, T.F. (1936) Some effects of androgenic substances in the rat. Science, N.Y. 84, 230-232.

Parvinen, M., Hurme, P. \& Niemi, M. (1970) Penetration of exogenous testosterone, pregnenolone, progesterone and cholesterol into the seminiferous tubules of the rat. Endocrinology 87, 1082-1084.

Sivelle, P.C., McNeilly, A.S. \& Collins, P.M. (1978) A comparison of the effectiveness of FSH, LH and prolactin in the reinitiation of testicular function of hypophysectomized and estrogen-treated rats. Biol. Reprod. 17, 878-885.

Steinberger, E. (1971) Hormonal control of mammalian spermatogenesis. Physiol. Rev. 51, 1-22.

Steinberger, E. \& Ficher, M. (1973) Effect of hypophysectomy and gonadotrophin treatment on metabolism of ${ }^{3} \mathrm{H}$-progesterone by rat testicular tissue. Steroids 22, 425-443.

Steinberger, E., Chowdhury, A.K., Tcholakian, R.K. \& Roll, H. (1975) Effects of $C_{21}$ steroids on sex accessory organs and testes of mature hypophysectomized rats. Endocrinology 96, 1319-1323.

Taché, Y., Selye, H., Szabo, S. \& Taché, J. (1973) Influence of pregnenolone-16a-carbonitrile on spermatogenesis and on the spermatogenic activity of pregnenolone. J. Endocr. 58, 233-238.

Tcholakian, R.K. \& Steinberger, A. (1978) Progesterone metabolism by cultured Sertoli cells. Endocrinology 103, 1335-1343.

Tsang, W.N., Collins, P.M. \& Lacy, D. (1973a) Steroid metabolism by the seminiferous tubules in vitro and spermatogenesis in the developing rat. $J$. Reprod. Fert. 34, 513-517.

Tsang, W.N., Lacy, D. \& Collins, P.M. (1973b) Leydig cell differentiation, steroid metabolism by the interstitium in vitro and the growth of the accessory sex organs in the rat. J. Reprod. Fert. 34, 351-355.

Walsh, E.L., Cuyler, W.K. \& McCullagh, D.R. (1934) Physiologic maintenance of the male sex glands; effect of androtin on hypophysectomized rats. $A m . J$. Physiol. 107, 508-512. 